\title{
Henryk Domański $\quad$ Ruchliwość społeczna i wzory zawierania małżeństw w Polsce
}

Social mobility and marital homogamy in Poland

This paper presents findings on the changes in social stratification in Poland, with particular attention given to mobility and marital choices. The author begins with an overview of the concept of social mobility, i.e. shifting of individuals or other categories in social space, including its definitions, indicators, patterns and mechanisms. Next, based on a set of empirical data, the author discusses the patterns of mobility and martial choices in the aftermath of 1989 transition in Poland. Special attention is given to the analysis of the openness of Polish society, opportunities for intergenerational mobility and its consequences.

\begin{tabular}{r|l}
\hline DOI & https://doi.org/10.31268/StudiaBAS.2020.13 \\
\hline Słowa kluczowe & $\begin{array}{l}\text { dziedziczenie, ruchliwość społeczna, stratyfikacja, struktura społeczna } \\
\text { W Polsce }\end{array}$ \\
\hline Keywords & inheritance, social mobility, stratification, social structure in Poland \\
\hline O autorze & $\begin{array}{l}\text { prof. dr hab., prof. zw., Instytut Filozofii i Socjologii Polskiej Akademii } \\
\text { Nauk } \bullet \text { hdomansk@ifispan.waw.pl } \\
\text { ORCID 0000-0001-5078-5027 }\end{array}$ \\
\hline
\end{tabular}

\section{Wstęp}

Ruchliwość, czyli każda zmiana pozycji przez ludzi, instytucje lub grupy zawodowe, jest jednym z elementów procesu kształtowania się nierówności społecznych. Analiza tego zjawiska wymaga wyjaśnienia, o jakie nierówności tu chodzi. W myśleniu potocznym nierówności są utożsamiane ze zróżnicowaniem położenia materialnego - są one efektem dystrybucji dóbr, które decydują o życiowych losach jednostek. Podejście to odbiega od socjologicznego rozumienia nierówności, w którym utożsamia się je z dziedziczeniem pozycji rodziców, barierami dostępu do wykształcenia, zasadami rekrutacji do ról zawodowych i odtwarzaniem się hierarchii społecznej, co nie musi występować w przypadku dystrybucji zarobków, emerytur czy opieki socjalnej.

W socjologii aspekt dystrybucyjny jest oddzielany od nierówności związanych z barierami edukacyjnymi, dostępem do określonych pozycji, „zamykaniem się” i ekskluzywnością. Nierówności rozpatrywane w tym drugim ujęciu są kojarzone ze stopniem otwartości struktury społecznej, nierównością szans i merytokracją. Rozróżnienie to wydaje się szczególnie istotne z punktu widzenia konsekwencji dla systemu społecznego i samych jednostek. Oczywiście nierówności szans nakładają się na nierówności dystrybucyjne ${ }^{1}$. Ważne są jedne i drugie. Niemniej w społeczeństwach rynkowych utrzymuje się przekonanie, że chociaż nierówności dystrybucyjne są nieuniknione - tzn. nie da się ich wyeliminować, chociaż można i należy je zmniejszać - to większym mankamentem są bariery otwartości społecznej. Są one bowiem nieracjonalne

1 W literaturze socjologicznej nierówności szans są określane mianem inequalities of opportunity, a nierówności dystrybucyjne - inequalities of outcomes. 
w kontekście możliwości rozwoju gospodarczego, stanowią zaprzeczenie demokracji, blokują dostęp do wysokich stanowisk ludziom utalentowanym, a w ocenie społecznej są uznawane za niesprawiedliwe.

W przeciwieństwie do krajów zachodnich, a zwłaszcza Stanów Zjednoczonych i Wielkiej Brytanii, w Polsce rozróżnienie to słabo rysuje się w świadomości społecznej. Hasło „równości szans” nie funkcjonuje w programach partii politycznych i w kampaniach wyborczych w takim stopniu jak w systemie brytyjskim, w którym stało się normą i jednym z niewielu przykładów zgodności między głównymi partiami. Występowało ono wyraźnie w zapowiedziach Tony'ego Blaira, że rząd Partii Pracy dopiero zaczyna walkę o zapewnienie prawdziwej równości² a następnie w rządzie konserwatystów Davida Camerona w postaci strategii walki z nierównościami, której kluczowym ogniwem był „wzrost ruchliwości społecznej"3. W podobnym duchu brzmiało exposé Theresy May (z lipca 2016 r.) - celem jej rządu miało być zapewnienie „wielkiej merytokracji” w sensie „równości szans" bez względu na pochodzenie społeczne. Z kolei politycy amerykańscy odwołują się do tych haseł we wszystkich wystąpieniach publicznych.

Najczęściej stosowanym wskaźnikiem otwartości struktury społecznej są wzory ruchliwości międzypokoleniowej. Ruchliwością jest każda zmiana pozycji społecznej. Występowanie słabszej zależności między pozycjami rodziców i dzieci traktowane jest jako świadectwo większej ruchliwości i słabszego dziedziczenia zasobów rodziny. O ile wpływ pochodzenia społecznego ogranicza możliwości awansu reprezentantom klas niższych, o tyle większa ruchliwość wyzwala inicjatywę, motywuje do przedsiębiorczości, wynagradza za kwalifikacje i zwiększa efektywność mechanizmów rynkowych. Teoretyczne argumenty na rzecz tej interpretacji przedstawiło wielu autorów i nie będę jej tutaj rozwijał ${ }^{4}$. Analizy porównawcze ${ }^{5}$ wskazują, że natężenie ruchliwości w Polsce nie odbiega od prawidłowości stwierdzonych w innych krajach ${ }^{6}$. Ale spójrzmy na te procesy z perspektywy zmian w czasie.

Celem tego artykułu jest próba odpowiedzi na pytanie, czy Polska staje się społeczeństwem otwartym. Żeby spojrzeć na kwestię otwartości szerzej, przeanalizuję również zmiany we wzorach zawierania małżeństw. Jest to drugi z najczęściej stosowanych wskaźników barier społecznych: zakłada się, że w im większym stopniu małżonkowie rekrutują się z tych samych

2 G. Payne, A New Social Mobility? The political redefinition of a sociological problem, "Contemporary Social Science" 2012, vol. 7(1), s. 55-71, https://doi.org/10.1080/21582041.2011.652360.

3 Cabinet Office Opening Doors Breaking Barriers, 2011, http://download.cabinetoffice.gov.uk/social-mobility/ opening-doors-breakingbarriers.pdf.

4 P. Sorokin, Ruchliwość społeczna, Wydawnictwo IFiS PAN, Warszawa 2009 (wydanie oryginalne - 1927);

R. Erikson, J.H. Goldthorpe, The Constant Flux: A Study of Class Mobility in Industrial Societies, Clarendon Press, Oxford 1992, https://doi.org/10.1177/000169939403700110.

5 Z. Sawiński, H. Domański, Wymiary struktury społecznej. Analiza porównawcza, Ossolineum, Wrocław 1986; B.W. Mach, Intergenerational mobility in Poland: 1972-88-94 [w:] Social Mobility in Europe, red. R. Breen, Oxford University Press, Oxford-New York 2004, s. 269-286, https://doi.org/10.1093/0199258457.003.0011.

6 Być może z wyjątkiem Szwecji - jedynego kraju, w którym konsekwentnie odnotowuje się wzrost ruchliwości międzypokoleniowej. Porównania międzykrajowe wskazują, że ruchliwość w Szwecji jest stosunkowo najwyższa. Social Mobility in Europe, red. R. Breen, Oxford University Press, Oxford-New York 2004, https:// doi.org/10.1093/0199258457.001.0001. 
środowisk pod względem pochodzenia społecznego, pozycji klasowej, poziomu wykształcenia ¡ innych aspektów, tym większe są bariery społeczne, albowiem większa homogamia małżeńska świadczy o większej ekskluzywności i ostrości podziałów klasowych ${ }^{7}$. I w tym przypadku stopień otwartości - mierzony w postaci różnicy między położeniem klasowym męża i żony - nie odbiega w Polsce od otwartości w innych społeczeństwach, chociaż - jak stwierdzono - w krajach postkomunistycznych występuje większa homogamia małżonków pod względem poziomu wykształcenia niż w krajach zachodnich. Równocześnie w latach 1987-2004 zwiększyła się w Polsce otwartość w zawieraniu małżeństw między osobami o różnej pozycji klasowej - przykładowo robotnicy wykwalifikowani coraz częściej wchodzili w związki małżeńskie z reprezentantami nowej inteligencji ${ }^{8}$. Nasuwa się pytanie, czy tendencje te utrzymywały się również w późniejszym okresie. Czy otwartość zwiększyła się, czy uległa zmniejszeniu?

Wszystkie te procesy analizowane są pod kątem ich konsekwencji dla funkcjonowania systemu społecznego i oddziaływania na postawy jednostek. Chodzi zwłaszcza o pozytywne i negatywne skutki awansu lub degradacji: ruchliwość „w górę” może być zaspokojeniem aspiracji życiowych, dostarczać satysfakcji, podnosić samoocenę, ale i rodzić napięcia oraz stresy związane z dostosowaniem się do nowego środowiska, z jego niechęcią, a nawet z odmową akceptacji. Z kolei ruchliwość „w dół” związana jest z utratą prestiżu i niemożnością dostosowania się do stylu życia klas niższych, do których się wchodzi. Przykładem może być robotnik budowlany lub sprzedawczyni w supermarkecie pochodzący, powiedzmy, z rodziny inteligenckiej. Ruchliwość w dół może prowadzić do poczucia degradacji, wywołuje potrzebę dystansowania się wobec klas niższych i podkreślania przynależności do klasy, którą się opuściło: byłaby to np. strategia obrony przez udawanie, że nic się nie zmieniło, a jeżeli - to tylko na krótko. Ustalenie skutków ruchliwości dla zachowań i postaw jest drugim celem moich analiz. Uzupełnię je wnioskami dotyczącymi konsekwencji przenikania się różnych klas społecznych w zawieraniu małżeństw. Będzie to próba wykazania, że ruchliwość i homogamia małżeńska są nie tylko abstrakcyjnymi pojęciami, ale mają odniesienie do rzeczywistości i wywołują określone reakcje.

\section{Podstawowe założenia}

Żeby uporządkować te zamierzenia analityczne, zacznę od problemu związanego z interpretacją wyników dotychczasowych badań nad ruchliwością społeczną. Jak stwierdziłem powyżej, większa ruchliwość traktowana jest jako kluczowe ogniwo przenikalności barier społecznych odróżnia społeczeństwa rynkowe od systemów stanowych, które opierały się na zasadzie dziedziczenia pozycji rodziców. Zgodnie z oczekiwaniami ruchliwość powinna się zwiększać - taka jest bowiem logika społeczeństw rynkowych. Prawidłowość tę dyktują zarówno warunki rozwoju ekonomicznego oraz zasady obsadzania stanowisk, jak i kryteria sprawiedliwości społecznej w społeczeństwach demokratycznych wyznacznikiem rekrutacji powinny być osiągnięcia jednostek, a nie pochodzenie społeczne, które jest poza ich kontrolą.

7 J.A. Schumpeter, Imperialism and Social Classes, Basil Blackwell, Oxford 1951.

8 H. Domański, D. Przybysz, Homogamia małżeńska i hierarchie społeczne, Wydawnictwo IFiS PAN, Warszawa 2007. 
Wbrew tym oczekiwaniom wskaźniki ruchliwości nie zwiększają się, a ujmując rzecz dokładniej, można stwierdzić, że nie występują tendencje, które wskazywałyby na systematyczny wzrost ruchliwości. W niektórych krajach, np. w Holandii i Francji, „czysty” wpływ pochodzenia społecznego ${ }^{9}$, tzn. ustalony niezależnie od zmian struktury zawodowej, zmniejszył się w drugiej połowie $X X$ w., jednak na ogół procesy te podlegają okresowym fluktuacjom ${ }^{10}$. W przypadku Anglii można wskazywać zarówno na oznaki zmniejszania się barier ruchliwości ${ }^{11}$, jak i na utrzymywanie się ich na stałym poziomie ${ }^{12}$. W Stanach Zjednoczonych, w których analizami objęto najdłuższe przedziały czasowe, odnotowywano na przemian wzrastający i malejący trend ze względu na otwartość struktury społecznej ${ }^{13}$. Generalnie, opierając się na danych z badań prowadzonych w latach 1972-2012, stwierdzono, że od XIX w. dokonywał się tam liniowy, chociaż nieznaczny wzrost otwartości ${ }^{14}$.

Podobnie jest w Polsce. Wyniki stosunkowo najnowszych analiz wskazują, że na początku lat 90. XX w. ruchliwość wśród mężczyzn zwiększyła się (wśród kobiet dokonało się to w latach 20022006), nie zmieniła się w następnym okresie, ale w latach 2012-2016 uległa zmniejszeniu ${ }^{15}$. Wzrost przenikalności barier społecznych mógł być zjawiskiem przejściowym, będącym naturalną konsekwencją zmiany ustroju politycznego, ale umocnienie się stosunków rynkowych w późniejszym okresie przywróciło mechanizmy dziedziczenia pozycji. W tym samym czasie nie wystąpiły żadne oznaki zwiększenia się przenikalności barier klasowych w zawieraniu małżeństw. Można by rzec,

9 Chodzi o oddzielenie zmiany pozycji społecznej „wymuszonej” przez zmiany struktury zawodowej (np. przez obniżenie odsetka rolników w strukturze społecznej, co powoduje, że część dzieci rolników musi przejść do kategorii robotników lub np. do inteligencji) od ruchliwości nazywanej „czystą”, związanej z obniżeniem się wpływu pochodzenia społecznego na osiągnięcia jednostek.

10 R. Breen, R. Luijkx, Social Mobility in Europe between 1970 and 2000 [w:] Social Mobility in Europe, red. R. Breen, Oxford University Press, Oxford-New York 2004, https://doi.org/10.1093/0199258457.003.0003; R. Breen, J.O. Jonsson, Inequality of Opportunity in Comparative Perspective: Recent Research on Educational Attainment and Social Mobility, „Annual Review of Sociology” 2005, vol. 31, s. 223-243, https://doi.org/10.1146/annurev. soc.31.041304.122232.

11 Y. Li, F. Devine, Is social mobility really declining? Intergenerational class mobility in Britain in the 1990s and the 2000s, „Sociological Research Online” 2011, vol. 16(3), s. 1-15, https://doi.org/10.5153/sro.2424; E. Bukodi, J.H. Goldthorpe, L. Waller, J. Kuha, The Mobility Problem in Britain: New Findings from the Analysis of Birth Cohort Data, „The British Journal of Sociology” 2015, vol. 66(1), s. 93-117, https://doi.org/10.1111/1468-4446.12096.

12 J.H. Goldthorpe, C. Mills, Trends in Intergenerational Class Mobility in Modern Britain: Evidence from National Surveys, 1972-2005, „National Institute Economic Review” 2008, vol. 205(1), s. 83-100, https://doi. org/10.1177/0027950108096591; J.H. Goldthorpe, M. Jackson, Intergenerational class mobility in contemporary Britain: Political concerns and empirical findings, "The British Journal of Sociology" 2007, vol. 58(4), s. 525-546, https://doi.org/10.1111/j.1468-4446.2007.00165.x.

13 J. Long, J. Ferrie, Intergenerational occupational mobility in Great Britain and the United States since 1850, „American Economic Review" 2013, vol. 103(4), s. 1109-1137, https://doi.org/10.1257/aer.103.5.2041; Y. Xie, A. Killewald, Intergenerational occupational mobility in Great Britain and the United States since 1850: Comment, „American Economic Review" 2013, vol. 103(5), s. 2003-2020, https://doi.org/10.1257/aer.103.5.2003; M. Hout, A.M. Guest, Intergenerational occupational mobility in Great Britain and the United States since 1850: comment, „American Economic Review” 2013, vol. 103(5), s. 2021-2040, https://doi.org/10.1257/aer.103.5.2021.

14 F.T. Pfeffer, F.R. Hertel, How Has Educational Expansion Shaped Social Mobility Trends in the United States?, „Social Forces" 2015, vol. 94(1), s. 143-180, https://doi.org/10.1093/sf/sov045.

15 H. Domański, B.W. Mach, D. Przybysz, Otwartość polskiej struktury społecznej: 1982-2016, „Studia Socjologiczne" 2019, nr 1(232), s. 25-63, https://doi.org/10.24425/122489. 
że reprezentanci kategorii o wyższym statusie niezmiennie skłaniają się do zawierania związków małżeńskich ze sobą. Tendencja do homogamii dotyczy również reprezentantów innych klas społecznych: pracowników umysłowych niższego szczebla, właścicieli firm, robotników i rolników ${ }^{16}$.

Nie można oczywiście wykluczyć, że zaskakujący brak kierunkowych zmian w otwartości struktury społecznej jest rezultatem nietrafnego pomiaru wskaźników ruchliwości i podziałów klasowych. Trzeba jednak podkreślić, że analizy dotyczące doskonalenia metodologii pomiaru są stale prowadzone i możemy je w tym miejscu pominąć. Moja interpretacja braku istotnych zmian w natężeniu ruchliwości jest następująca. Prawdopodobnie systemy rynkowe znalazły się na takim etapie rozwoju, na którym logika otwartości zderzyła się z logiką reprodukcji podziałów społecznych. W efekcie został osiągnięty stan równowagi. Nie jest to nowa myśl - uzasadnienie korzyści ze stanu równowagi społecznej przedstawił już ponad 100 lat temu Vilfredo Pareto ${ }^{17}$, rozpatrując to z perspektywy teorii o „cyrkulacji elit”, będącej jednym z pierwszych odniesień do ruchliwości międzypokoleniowej. Wiadomo, że struktura społeczna, z jednej strony, opiera się na trwaniu i stabilności, a z drugiej - jest dynamicznym układem instytucji, które dostosowują się do zmian gospodarki, polityki, kultury, na rynku pracy, życia rodzin, w tym także relacji między małżonkami. Funkcjonowanie nowoczesnych społeczeństw jest powiązane z modernizacją, jednak nie powinna ona naruszać stanu harmonii między dynamiką a ładem i stabilnością. Dotyczy to również przemieszczania się ludzi między pozycjami społecznymi i przynależnością klasową. Rzeczą pożądaną i warunkiem normalizacji jest utrzymanie proporcji między zasadami merytokracji i awansem społecznym a oddziaływaniem pochodzenia społecznego i dziedziczenia pozycji rodziców. Inaczej mówiąc: niezgodne z oczekiwaniami wyniki badań wskazujące na zahamowanie procesów otwierania się struktury społecznej mogą świadczyć o tym, że najważniejsze zmiany mamy za sobą. Najistotniejsze z nich dokonały się przy przechodzeniu od społeczeństw tradycyjnych do kapitalistycznych; w następnym okresie miał miejsce stopniowy wzrost otwartości, ale na obecnym etapie rozwoju ruchliwość międzypokoleniowa osiągnęła maksimum i nie będzie się zwiększać.

Wyjaśnienie to skonfrontuję z alternatywną hipotezą o zwiększaniu się ruchliwości międzypokoleniowej i heterogamii w zawieraniu małżeństw. W przypadku Polski przemawiają za nią utrzymywanie się tendencji do wzrostu gospodarczego i towarzyszący temu wzrost zapotrzebowania na pozycje lokujące się na wyższych piętrach hierarchii społecznej. Potwierdzeniem tego są ustalenia płynące $z$ analiz dotyczących zmian struktury społeczno-zawodowej. W latach 1988-2018 odsetek kierowników wyższego szczebla i specjalistów, a więc kategorii lokujących się na stosunkowo wysokich pozycjach, zwiększył się z 7,2 do 13,4 ogółu zatrudnionych. Drugim czynnikiem jest wyłanianie się nowych mechanizmów rekrutacji do ról zawodowych. Oprócz elastycznych form zatrudnienia, związanych z dostosowywaniem się przedsiębiorstw do cykliczności procesów rynkowych, takich jak praca na okresowym kontrakcie, chodzi o przyuczanie pracowników do profilu firmy i przechodzenie do realizacji nowych zadań w zależności od zmieniających się potrzeb. z kolei czynnikami sprzyjającymi rozmywaniu się barier klasowych w zawieraniu małżeństw są wzrost wykształcenia kobiet i związany z tym wzrost aktywności

16 H. Domański, D. Przybysz, op. cit.

17 V. Pareto, Traktat o socjologii ogólnej, 1916. 
zawodowej. Przewaga kobiet z wyższym wykształceniem w stosunku do mężczyzn wymusza w pewnym sensie heterogamię klasową, niezależnie od kierowania się przez mężczyzn preferencjami związanymi z wyglądem przyszłych partnerek życiowych, posiadaniem przez obojga wspólnych wartości i podobieństwem stylu życia.

\section{Dane}

Hipoteza o permanentnej fluktuacji kontrastuje więc z hipotezą o zwiększaniu się otwartości społecznej. Obie hipotezy zweryfikuję na podstawie danych z badań realizowanych w latach 1988-2019. Wszystkie próby dobierano metodą losową. Dane pochodzące z badania "Struktura społeczna II" (pierwsza edycja badania nazwanego później POLPAN-em) uzyskano na podstawie imiennej próby 5817 respondentów ${ }^{18}$. W odniesieniu do lat 1992-2010 odwołuję się do danych Polskiego Generalnego Sondażu Społecznego, realizowanego na próbach adresów domowych, w których liczba respondentów kształtowała się w granicach 1250-1700. Zbiór danych z 2013 r. pochodzi z badania POLPAN (kontynuacja „Struktury społecznej II”), przeprowadzonego na próbie 2780 respondentów. Dane dla 2018 r. pochodzą z 8. rundy Europejskiego Sondażu Społecznego, realizowanego na próbie imiennej, która objęła 1721 wywiadów. Jeśli chodzi o ostatni z rozpatrywanych punktów czasowych, korzystam z danych pochodzących z badania „Dystynkcje muzyczne. Gust muzyczny i stratyfikacja społeczna a procesy kształtowania się stylów życia Polaków", zrealizowanego w 2019 r. na próbie 2041 osób ${ }^{19}$. Ponieważ badanie z 1988 r. realizowane było na respondentach w wieku 21-65 lat, ograniczenie to zastosowałem w celu zachowania porównywalności do wszystkich tych badań.

Aby ustalić wzory ruchliwości międzypokoleniowej, posłużyłem się klasycznymi tabelami, w których kategorie respondentów w roku badania rozpatrywane są ze względu na kategorie rodziców. W mojej analizie są nimi ojcowie, których pozycja klasowa lepiej identyfikuje pochodzenie społeczne niż kategorie matek. W analizach nad ruchliwością jest to najczęściej stosowane podejście, które pozwala na ustalenie zmian przynależności klasowej i dziedziczenia pozycji. Przeanalizuję pod tym kątem rozkłady zależności między sześcioma klasami ojców ze względu na sześć identycznych klas respondentów ${ }^{20}$. Wyróżniłem sześć klas:1) wyższe kadry kierownicze przedsiębiorstw, wysocy urzędnicy państwowi i specjaliści, 2) pracownicy umysłowi niższego szczebla, m.in. kierownicy wydziałów, technicy, pielęgniarki, księgowi, urzędnicy wykonujący rutynowe prace biurowe oraz szeregowi pracownicy w usługach i handlu (np. sprzedawczynie, fryzjerzy, kasjerki na poczcie, kelnerzy), 3) właściciele firm i samozatrudniający się właściciele poza rolnictwem, 4) robotnicy wykwalifikowani, 5) robotnicy niewykwalifikowani, 6) rolnicy, czyli właściciele gospodarstw i robotnicy rolni. W większości krajów jest to najczęściej stosowany schemat podziałów klasowych, który - jak wynikałoby z dotychczasowych ustaleń - pozwala

18 K.M. Słomczyński, I. Białecki, H. Domański, K. Janicka, B.W. Mach, Z. Sawiński, J. Sikorska, W. Zaborowski, Struktura społeczna: schemat teoretyczny i warsztat badawczy, Wydawnictwo IFiS PAN, Warszawa 1989.

19 Projekt realizowany przez Instytut Filozofii i Socjologii Polskiej Akademii Nauk ze środków Narodowego Centrum Nauki przyznanych na mocy umowy nr UMO-2017/25/B/HS6/01929. Kierownikiem projektu jest Henryk Domański.

20 Przynależność klasowa ojców dotyczy sytuacji, gdy respondenci mieli 14 lat. 
zidentyfikować najistotniejsze bariery społeczne ${ }^{21}$. Ten sam schemat zastosowałem w analizie wzorów zawierania małżeństw, tak więc wszystkie tabele były tu dwuwymiarowym rozkładem sześciu klas społecznych męża skrzyżowanych z sześcioma klasami żony. Pozwala to na uchwycenie małżonków wywodzących się z różnych klas i małżeństw homogamicznych klasowo. Ze względów stylistycznych (w celu uniknięcia powtórzeń) pojęcie „klasy społecznej” będę stosował wymiennie z pojęciem „kategorii społeczno-zawodowej” (zawód jest stosunkowo najbardziej trafnym wskaźnikiem przynależności klasowej).

\section{Zmiany w otwartości}

Dane przedstawione w tabeli 1 informują o otwartości struktury społecznej w Polsce. W pierwszej kolumnie zamieściłem odsetki osób zmieniających przynależność klasową (a dokładniej lokujących się poza główną przekątną tabeli ruchliwości), w drugiej kolumnie - odsetki osób, których małżonkami są reprezentanci innej klasy społecznej.

\section{Tabela 1. Otwartość struktury społecznej w Polsce w latach 1988-2019}

\begin{tabular}{|l|c|c|c|c|}
\hline $\begin{array}{c}\text { Rok } \\
\text { badania }\end{array}$ & $\begin{array}{c}\text { Odsetki ruchliwości } \\
\text { międzypokoleniowej }\end{array}$ & $\begin{array}{c}\text { Odsetki } \\
\text { heterogamii } \\
\text { małżeńskiej }\end{array}$ & $\begin{array}{c}\text { Siła związku } \\
\text { mięqzy klasami } \\
\text { społecznymi ojców } \\
\text { i respondentów }\end{array}$ & $\begin{array}{c}\text { Siła związku } \\
\text { między klasami } \\
\text { społecznymi męźów } \\
\text { i żona }\end{array}$ \\
\hline 1988 & 73,9 & 71,7 & 1,00 & 1,00 \\
\hline 1992 & 77,0 & 73,6 & 1,07 & 1,07 \\
\hline 1995 & 70,4 & 75,8 & 1,04 & 0,90 \\
\hline 1998 & 67,5 & b.d. & 1,06 & b.d. \\
\hline 2002 & 70,4 & 74,7 & 0,86 & 0,94 \\
\hline 2005 & 70,0 & 74,2 & 0,91 & 1,08 \\
\hline 2007 & 71,8 & 73,2 & 1,04 & 0,89 \\
\hline 2010 & 74,1 & 73,2 & 0,94 & 0,83 \\
\hline 2013 & 72,2 & 70,0 & 0,91 & 0,79 \\
\hline 2019 & 67,9 & 68,3 & 1,29 & 0,87 \\
\hline
\end{tabular}

a Są to parametry siły związku między przynależnością klasową ojców i respondentów (lub małżonków) uzyskane w ramach unidifference model 22 .

b.d. - brak danych

W latach 1988-2019 odsetki osób zmieniających przynależność klasową oscylowały między 67 a 77. Widać, że ruchliwość międzypokoleniowa systematycznie ani się nie zwiększała, ani się nie zmniejszała. Pomiędzy 1988 a 1992 r. dokonał się pewien wzrost ruchliwości (z 73,9\% do 77\%),

21 R. Erikson, J.H. Goldthorpe, op. cit.

22 H. Domański, B.W. Mach, D. Przybysz, op. cit. 
był on jednak stosunkowo nieduży i nie znamionował zasadniczych zmian w przełamywaniu barier klasowych. Nie można wykluczyć, że mamy do czynienia z efektem niejednakowej liczebności respondentów i związanych z tym błędów losowych: próba z 1988 r. była 3-krotnie większa w porównaniu z badaniami z 1992 r. Wzrost ruchliwości może być również wynikiem nieuniknionego w badaniach surveyowych błędu w identyfikacji przynależności klasowej ojców i respondentów.

Potwierdzeniem hipotezy o braku większych zmian w czasie są również wzory zawierania małżeństw. W latach 2005-2019 zmniejszył się wprawdzie odsetek małżonków reprezentujących różne klasy społeczne (z 74\% do 68\%), może to być jednak konsekwencją upodobniania się struktury społeczno-zawodowej mężczyzn i kobiet, a nie zaostrzenia się barier klasowych. Zmiany struktury zawodowej wymuszają wzrost homogamii klasowej, co niekoniecznie wskazuje na obniżanie się otwartości barier społecznych. Najbardziej sfeminizowaną kategorią są pracownicy umysłowi niższego szczebla (personel biurowy, sekretarki, kasjerki, sprzedawczynie itd.). W latach 1992-2019 liczebność tej kategorii zwiększyła się z 26,8\% do 39,5\%. Równocześnie zmniejszyła się (z 19,3\% do 14,8\%) liczebność najbardziej zmaskulinizowanej kategorii - robotników wykwalifikowanych. Prawdopodobnie więc jakaś część kobiet, które chciały wyjść za mąż, nie musiała wybrać partnera z klas niższych.

Za interpretacją odwołującą się do efektu strukturalnego przemawiają wyniki analizy przedstawione w dwóch ostatnich kolumnach tabeli 1. Należy podkreślić, że tabele ruchliwości, z jednej strony, są odzwierciedleniem zmian liczebności kategorii rodziców i dzieci, a z drugiej identyfikują komponent ruchliwości względnej, tzn. niezależnej od zmiany liczebności. Zdaniem wielu badaczy dopiero komponent ruchliwości względnej informuje o otwartości struktury społecznej i ostrości dystansów klasowych. W świetle tej argumentacji wyjątkowo silny wzrost ruchliwości w Polsce w latach 1950-1955, związany z procesami uprzemysłowienia, nie stanowi wystarczającego dowodu, że dokonało się wtedy otwarcie struktury społecznej ${ }^{23}$. Byłoby tak, gdyby pojawiły się mechanizmy osłabiające wpływ pochodzenia na pozycję społeczną jednostek, czego efektem byłoby zacieranie się wyrazistości podziałów klasowych. Skądinąd wiadomo jednak, że ów wpływ się nie zmniejszył, a wzrost ruchliwości został wymuszony przez potrzeby "obsadzania" nowych pozycji w przemyśle, budownictwie i administracji państwowej.

Komponent ruchliwości względnej zwykło się specyfikować za pomocą wskaźników uzyskiwanych w ramach modeli logarytmiczno-liniowych. W celu ich ustalenia posłużyłem się modelem określanym mianem „jednakowej różnicy” (uniform difference model). Wartości parametrów dla ruchliwości względnej zamieszczone są w trzeciej kolumnie tabeli 1 - w czwartej kolumnie przedstawiłem je dla wzorów zawierania małżeństw. Wartości wyższe od 1 wskazują na większą, a wartości mniejsze od 1 - na mniejszą siłę barier społecznych w porównaniu z 1988 r., który jest punktem referencyjnym. Widać, że bariery ruchliwości międzypokoleniowej charakteryzowały się największą otwartością w 2002 r. (0,86), a najmniejszą w 2019 r. (1,29), w sumie jednak różnice między wartościami parametrów wydają się przypadkowe i nie układają się w jednokierunkową tendencję. Podobnie jest z barierami zawierania małżeństw. Podsumowując, należy stwierdzić, że jesteśmy społeczeństwem stosunkowo otwartym, w którym ruchliwość międzypokoleniowa

23 K. Zagórski, Rozwój, struktura i ruchliwość społeczna, PWN, Warszawa 1978. 
dominuje nad dziedziczeniem pozycji rodziców, a heterogamia klasowa przeważa nad małżeństwami homogamicznymi. Jednak nic nie wskazuje na wzrost otwartości struktury społecznej. W szczególności zjawiska te nie były związane ze zmianami systemu społeczno-politycznego, przystąpieniem do Unii Europejskiej ani z przechodzeniem na tory gospodarki rynkowej.

\section{Konsekwencje ruchliwości}

Zakładając, że brak większych zmian otwartości struktury społecznej jest stanem równowagi, do którego doszliśmy na obecnym etapie rozwoju, zobaczmy, jak zmiana pozycji klasowej oddziałuje na zachowania i postawy jednostek. Oceniając skutki ruchliwości międzypokoleniowej, należy brać pod uwagę, że awansowi społecznemu towarzyszy konieczność dostosowywania się osób ruchliwych do nowego środowiska pod względem zachowań, stylu życia i innych aspektów, które oddziałują na status społeczny. Osoby ruchliwe pochodzą z klas niższych. Przyzwyczajenia i wzory, które zostały przez nie wyniesione z dzieciństwa, zderzają się z innym językiem, stylem prowadzenia rozmowy, sposobami ubierania się, spędzania wolnego czasu, preferencjami w zakresie czytania książek, jedzenia, oglądania telewizji i gustów muzycznych. Wpływ pochodzenia społecznego rzutuje również na preferencje partyjne: np. w Anglii członkowie klasy średniej o pochodzeniu robotniczym częściej głosują na Partię Pracy niż członkowie klasy średniej dziedziczący pozycję społeczną rodziców ${ }^{24}$. Niezależnie od tego ruchliwość „w górę” wymaga akceptacji przez kategorie, do których się wchodzi. Osoby pochodzące z klas niższych napotykają bariery kulturowe związane z praktykami ekskluzywności stosowanymi przez kategorie zajmujące wysokie pozycje społeczne. Jeżeli chodzi o negatywne konsekwencje degradacji społecznej, to w społeczeństwach, które funkcjonują pod presją sukcesu, utrata pozycji uznawana jest za świadectwo niepowodzenia, niedostosowania się do reguł rynkowych i braku użyteczności. Zajmowanie niższej pozycji w porównaniu z pozycją rodziców jest sygnałem, że osoby te nie sprostały oczekiwaniom społecznym, nie sprawdziły się, a więc nie zasługują na zajmowanie wysokich stanowisk, co obniża samoocenę i powoduje stres ${ }^{25}$. Występowanie tych zjawisk prowadzi do wniosku, że zmiana pozycji społecznej jest elementem złożonego procesu przełamywania barier klasowych. Sprzyja to dekompozycji cech położenia społecznego i sytuuje osoby ruchliwe na pograniczu różnych zachowań i postaw.

$Z$ dotychczasowych analiz wynika, że zależności te mogą występować w różnych wariantach. Zweryfikuję trzy hipotezy. Pierwsza z nich dotyczy efektu "socjalizacji"26. Polega on na tym, że osoby, które przesunęły się na górne piętra hierarchii społecznej, podlegają silniejszemu oddziaływaniu kultury wyniesionej ze środowiska rodzinnego w porównaniu z kulturą kategorii, w której są teraz. Wzory wyuczone w dzieciństwie dominują, ponieważ ludzie pochodzący z klas niższych nie chcą - lub nie potrafią - pozbyć się wartości, w których byli wychowywani.

24 P. Clifford, A.F. Heath, The political consequences of social mobility, , Journal of the Royal Statistical Society. Series A" 1993, vol. 156, s. 51-61, https://doi.org/10.2307/2982860.

25 K.S. Newman, Falling from grace: downward mobility in the age of affluence, University of California Press, Berkeley 1999, https://doi.org/10.2307/2073805.

26 P. Coulangeon, The Omnivore and the "Class Defector". Musical Taste and Social Mobility in Contemporary France, "Notes \& Documents" 2013, no. 3. 
Odwrotny mechanizm występuje w przypadku efektu „maksymalizacji”27. Ruchliwości „w górę" towarzyszy w tym przypadku potrzeba dostosowania się do stylu klasy zajmującej wyższą pozycję społeczną. Osoby awansujące nie czują się od niej izolowane, a przede wszystkim zależy im na upodobnieniu się do niej. Strategia „maksymalizacji” działa też w drugą stronę: osoby ruchliwe w dół mają poczucie degradacji społecznej, zależy im na odzyskaniu utraconej pozycji, dlatego też robią wszystko, żeby zachować styl klasy społecznej, którą opuścili. Chcą uchodzić za lepszych niż są, udają więc przed innymi i sobą, że jest to sytuacja przejściowa.

Rozwiązaniem pośrednim jest połączenie obu efektów (ang. culture switching). Zgodnie z tą hipotezą zwyczaje wyniesione z klasy społecznej, w której ludzie się urodzili i byli socjalizowani, są łączone z wartościami klasy, do której przeszli, czyli jest to połączenie efektu "socjalizacji” ze strategią "maksymalizacji”. Jest to np. przypadek specjalistów pochodzących z klasy robotniczej, którzy wprawdzie nie słuchają muzyki poważnej tak często jak specjaliści o rodowodzie inteligenckim, ale lubią ją bardziej niż członkowie klas niższych.

Ruchliwość oddziałuje na różne aspekty. Zacznijmy od zależności z poziomem dochodów, które w sekwencji przyczynowej poprzedzają postawy i zachowania jednostek. Dane w tabeli 2 dają wgląd w oddziaływanie ruchliwości na dochody rodziny (wyjaśnianym zjawiskiem jest dochód na osobę ${ }^{28}$. Wartości przedstawione w komórkach tabeli informują o dochodach osób, które zmieniły przynależność klasową (tzn. tych lokujących się poza główną przekątną), i osób dziedziczących pozycję rodziców (usytuowanych na głównej przekątnej). Wartości dodatnie wskazują, o ile większe były dochody tych kategorii w porównaniu ze średnimi dochodami, a wartości ujemne - o ile były one niższe. Jeśli wziąć pod uwagę, że ustaliłem je przy kontroli wieku, płci, wielkości miejsca zamieszkania, a przede wszystkim przynależności klasowej respondentów i ojców, mogą być one interpretowane jako charakterystyka w miarę "czystego" wpływu ruchliwości międzypokoleniowej i dziedziczenia pozycji. Z kolei dane zamieszczone w ostatnim wierszu tabeli są charakterystyką „czystego” wpływu przynależności klasowej respondentów, a dane w ostatniej kolumnie wskazują na "czysty" wpływ klasy społecznej ojca.

Wyniki te są potwierdzeniem znanych prawidłowości wskazujących na uzyskiwanie najwyższych dochodów przez kierowników wysokiego szczebla i specjalistów, a stosunkowo najniższych przez robotników niewykwalifikowanych i rolników ${ }^{29}$. Dystans między dochodami kierowników i specjalistów a średnią krajową kształtował się na poziomie 805 zł, niezależnie od pochodzenia społecznego, miejsca zamieszkania, wieku i płci. Na drugiej pozycji lokowali się pracownicy umysłowi niższego szczebla (774 zł), za nimi prywatni przedsiębiorcy (663 zł), a na dole robotnicy niewykwalifikowani z dochodami powyżej średniej na poziomie 300 zł (na samym dole są dochody rolników, którzy są kategorią referencyjną). Natomiast nie występowały statystycznie znaczące różnice między dochodami kategorii zmieniających przynależność kla-

27 S. Daenekindt, H. Roose, Cultural chameleons, „Acta Sociologica” 2013, vol. 56(4), s. 309-324, http://dx.doi. org/10.1177/0001699313496589.

28 Analizy, które dotyczą oddziaływania ruchliwości na dochody oraz postawy jednostek, a których wyniki przedstawiam w tabelach 2-4, pochodzą z badania „Dystynkcje muzyczne. Gust muzyczny i stratyfikacja społeczna a procesy kształtowania się stylów życia Polaków", zrealizowanego w 2019 r. na próbie ogólnopolskiej.

29 H. Domański, Czy sq w Polsce klasy społeczne, Krytyka Polityczna, Warszawa 2015. 
sową ani też dochodami osób niezmieniających pozycji. Ani awans, ani degradacja klasowa nie oddziaływały więc w istotnym stopniu na poziom zamożności. Uwzględniając te zastrzeżenie, zwracam uwagę, że stosunkowo najbardziej opłacalnym wzorem kariery okazuje się dziedziczenie pozycji rodziców. Zgodnie z przewidywaniami najwyższe dochody uzyskiwali członkowie klasy uprzywilejowanej, kierownicy wyższego szczebla i specjaliści, którzy charakteryzują się najwyższym kapitałem kulturowym i kontaktami towarzyskimi i którzy równocześnie wywodzili się z tej klasy społecznej (1355 zł). Korzystnie rysował się również napływ do kategorii kierowników i specjalistów z kategorii właścicieli. Osoby te uzyskiwały średnio o 1063 zł większe dochody w porównaniu ze średnią krajową. Była to jakby premia za rodzaj szczególnego aliansu między zajmowaniem przez nie obecnej pozycji klasowej a przedsiębiorczością wyniesioną z domu i kapitałem płynącym z własności rodziców.

\section{Tabela 2. Zależności między ruchliwością międzypokoleniową a dochodami rodziny na osobę w 2019 r. (w zł)}

\begin{tabular}{|c|c|c|c|c|c|c|c|}
\hline \multicolumn{8}{|c|}{ Przynależność klasowa respondentów w 2019 r. } \\
\hline Przynależność klasowa ojców & 1 & 2 & 3 & 4 & 5 & 6 & ogółem \\
\hline 1. Wyżsi kierownicy i specjaliści & 1355 & -881 & 64 & b.d. & b.d. & b.d. & $1935^{\star}$ \\
\hline $\begin{array}{l}\text { 2. Pracownicy umysłowi niższego } \\
\text { szczebla }\end{array}$ & 723 & -754 & 491 & -456 & b.d. & b.d. & 760 \\
\hline 3. Właściciele firm & 1063 & 13 & -45 & -116 & 301 & b.d. & -30 \\
\hline 4. Robotnicy wykwalifikowani & 395 & -154 & 15 & -75 & 428 & b.d. & 233 \\
\hline 5. Robotnicy niewykwalifikowani & -20 & 366 & 659 & -22 & 603 & b.d. & -90 \\
\hline 6. Rolnicy & Ref. & Ref. & Ref. & Ref. & Ref. & Ref. & Ref. \\
\hline Ogółem & 805 & $774^{* \star}$ & $663^{*}$ & $553^{*}$ & 300 & Ref. & \\
\hline
\end{tabular}

** $p<0,01, * p<0,01$

b.d. - brak danych

Zgodnie z hipotezami zmiany pozycji klasowej powinny aktywizować strategie „socjalizacji”, „maksymalizacji” lub „dostosowania się” pod względem stylu życia i innych aspektów. Występowanie tych zależności stwierdzono m.in. w Anglii i Francji. Ruchliwość „w górę”, a w szczególności przechodzenie z klasy robotniczej do średniej, sprzyjała większym upodobaniom do kultury wyrafinowanej, utożsamianej z muzyką poważną. Okazuje się również, że charakterystyczną cechą członków klasy średniej, którzy rekrutowali się z klasy robotniczej, była tendencja do łączenia upodobań do muzyki rozrywkowej, związanej z pochodzeniem społecznym, ze strategią „maksymalizacji” (ang. culture switching), tzn. gustowaniem w muzyce poważnej ${ }^{30}$.

30 P. Coulangeon, op. cit:; T. Chan, H. Turner, Where Do Cultural Omnivores Come from? The Implications of Educational Mobility for Cultural Consumption, Paper presented at the International Sociological Association RC28 Conference in Budapest, April 2014, 2015, https://doi.org/10.1093/esr/jcx060. 
Tabela 3. Zależności między ruchliwością międzypokoleniową a chodzeniem do filharmonii, opery lub na przedstawienia baletowe w 2019 r.

\begin{tabular}{|c|c|c|c|c|c|c|c|}
\hline \multicolumn{8}{|c|}{ Przynależność klasowa respondentów w 2019 r. } \\
\hline Przynależność klasowa ojców & 1 & 2 & 3 & 4 & 5 & 6 & ogółem \\
\hline 1. Wyżsi kierownicy i specjaliści & 18,6 & 18,6 & 18,9 & 0,38 & 20,6 & b.d. & $-9,7$ \\
\hline $\begin{array}{l}\text { 2. Pracownicy umysłowi niższego } \\
\text { szczebla }\end{array}$ & 17,9 & 18,5 & 19,2 & 19,2 & 19,2 & b.d. & $-10,1^{* *}$ \\
\hline 3. Właściciele firm & $-2,0$ & 1,4 & 1,5 & 1,6 & 1,7 & b.d. & 10,9 \\
\hline 4. Robotnicy wykwalifikowani & 17,5 & 17,7 & 17,4 & 18,4 & 17,8 & b.d. & $-9,9$ \\
\hline 5. Robotnicy niewykwalifikowani & $-3,3^{* *}$ & $-3,2^{\star}$ & $-3,3^{*}$ & $-20,5$ & $-21,1$ & b.d. & 10,6 \\
\hline 6. Rolnicy & Ref. & Ref. & Ref. & Ref. & Ref. & Ref. & Ref. \\
\hline Ogółem & $1,4^{\star \star}$ & $0,57^{*}$ & 0,72 & $-1,1^{*}$ & $-0,06$ & Ref. & \\
\hline
\end{tabular}

${ }^{* *} p<0,01,{ }^{*} p<0,05$

W tabeli 3 przedstawiam wyniki analizy dotyczącej oddziaływania ruchliwości na chodzenie na koncerty muzyki poważnej do filharmonii, opery lub na przedstawienia baletowe ${ }^{31}$. Podobnie jak w analizie zależności z dochodami ustaliłem je przy uwzględnieniu innych cech respondentów ${ }^{32}$. Zgodnie z oczekiwaniami najczęściej chodzili do filharmonii kierownicy wyższego szczebla i specjaliści (o 1,4 raza częściej w stosunku do średniej), przed właścicielami $(0,72)$ i pracownikami umysłowymi $(0,57)$. W przedsięwzięciach tych wyjątkowo rzadko uczestniczyli robotnicy i rolnicy - rzadziej w stosunku do średniej o od 0,06 do 1,1. Natomiast konsekwencje ruchliwości międzypokoleniowej są raczej znikome. Interesujący i statystycznie istotny okazuje się tylko wpływ pochodzenia z grupy robotników niewykwalifikowanych. Osoby wywodzące się z tej kategorii, które awansowały w hierarchii klasowej, miały zdecydowanie najmniej szans uczęszczania na koncerty, przedstawienia baletowe i do opery. Zależność ta występuje nawet przy przechodzeniu do grupy kierowników i specjalistów, nie mówiąc o właścicielach i pracownikach biurowych. Posiadanie ojca robotnika niewykwalifikowanego zmniejszało szanse pójścia do filharmonii wśród kierowników i specjalistów o 3,3 razy w stosunku do średniej, podobnie było w przypadku przechodzenia do kategorii właścicieli i pracowników umysłowych. Wynikałoby stąd, że wzory praktykowania kultury wyniesione z własnego środowiska dominują, co

31 Respondenci odpowiadali na pytanie: Jak często bywa Pan/i na koncercie muzyki poważnej w filharmonii, w operze, na przedstawieniu baletowym. Odpowiedzi obejmowały 6-punktową skalę od: nigdy nie byłem(am) do raz na miesiq̨c lub częściej. Osobom, które deklarowały chodzenie co najmniej raz w roku, przypisałem 1, pozostałym 0.

32 Ponieważ wyjaśnianym zjawiskiem jest zmienna dychotomiczna (chodzi-nie chodzi), posłużyłem się analizą regresji logistycznej. Stąd też wielkości przedstawione w tabeli 3 informują, o ile częściej osoby ruchliwe lub dziedziczące pozycję klasową chodziły do filharmonii itd. w porównaniu z osobami, które nie chodziły. Wielkości te są wyrażone w postaci logarytmicznej. 
potwierdza hipotezę o efekcie "socjalizacji”. Są czynnikiem blokującym dostosowanie się do norm klasy społecznej, do której się awansuje. Być może wynikają ze świadomego wyboru.

Zmiana przynależności klasowej słabo różnicuje również inne rodzaje zachowań. Ilustrują to wskaźniki siły związku między czytelnictwem książek a ruchliwością międzypokoleniową (tabela 4). Wyniki wszystkich badań dowodzą, że czytelnikami książek są głównie członkowie klas uprzywilejowanych, o wysokim kapitale kulturowym i absolwenci wyższych uczelni ${ }^{33}$. Oczywiście ludzi różnicuje nie tylko fakt samego czytania, ale czytanie określonego gatunku książek, zwłaszcza trudnych powieści z dziedziny literatury klasycznej. Książki są czytane dla przyjemności, ale czynnikiem wzmacniającym jest łatwość w rozumieniu tekstu i potrzeby estetyczne związane z wykonywaniem ról zawodowych charakteryzujących się większą złożonością i wysokimi kompetencjami.

Tabela 4. Zależności między ruchliwością międzypokoleniową a czytaniem książek w 2019 r.

\begin{tabular}{|c|c|c|c|c|c|c|c|}
\hline \multicolumn{8}{|c|}{ Przynależność klasowa respondentów w 2019 r. } \\
\hline Przynależność klasowa ojców & 1 & 2 & 3 & 4 & 5 & 6 & ogółem \\
\hline 1. Wyżsi kierownicy i specjaliści & 19,0 & 20,2 & 20,2 & 20,5 & 20,3 & Ref. & $-12,7$ \\
\hline $\begin{array}{l}\text { 2. Pracownicy umysłowi niższego } \\
\text { szczebla }\end{array}$ & 0,91 & 0,41 & 0,95 & 0,85 & 0,86 & Ref. & 6,9 \\
\hline 3. Właściciele firm & $-0,87$ & 0,34 & $-1,14$ & $-0,28$ & $-0,69$ & Ref. & 7,2 \\
\hline 4. Robotnicy wykwalifikowani & 18,2 & 19,9 & 19,7 & 20,2 & 20,3 & Ref. & $-13,4$ \\
\hline 5. Robotnicy niewykwalifikowani & 0,01 & 0,68 & 1,48 & 1,00 & 1,32 & Ref. & 5,5 \\
\hline 6. Rolnicy & Ref. & Ref. & Ref. & Ref. & Ref. & Ref. & Ref. \\
\hline Ogółem & $1,8^{* *}$ & 0,34 & 0,07 & $-0,51^{*}$ & $-1,04^{\star *}$ & Ref. & \\
\hline
\end{tabular}

${ }^{* *} p<0,01,{ }^{*} p<0,05$

Prawidłowości te znajdują potwierdzenie w danych z badań dla Polski. Czytelnicy książek wyraźnie dominują w kategorii kierowników wyższego szczebla i specjalistów $(1,8)$, niezależnie od pochodzenia społecznego i pozycji klasowej, a poza tym wielkości miejsca zamieszkania, wieku i płci. Na drugim miejscu sytuują się pracownicy umysłowi niższego szczebla $(0,34)$, którzy wyprzedzają właścicieli $(0,07)$. Relacja między tymi kategoriami rysowała się odwrotnie niż przy chodzeniu do filharmonii czy opery, co oznaczałoby, że aktywne praktykowanie kultury wynika też z zamożności i położenia materialnego. Pracowników biurowych rzadziej stać na bilet do filharmonii w porównaniu z właścicielami, podczas gdy książki są tańsze, można je też wypożyczać.

Czytanie książek jest słabo związane z ruchliwością społeczną. W szczególności nic nie wskazuje na to, żeby przechodzenie do wyższej kadry kierowniczej i specjalistów było impulsem sprzyjającym większemu czytelnictwu - byłaby to łatwa do zrozumienia reakcja, wynikająca z potrzeby

33 W. Griswold, T. McDonnell, N. Wright, Reading and the Reading Class in the Twenty-First Century, "Annual Review of Sociology" 2005, vol. 31, s. 127-141, https://doi.org/10.1146/annurev.soc.31.041304.122312. 
bycia zaakceptowanym przez specjalistów dziedziczących pozycje rodziców. Z danych przedstawionych w pierwszej kolumnie tabeli 4 wynika, że - z wyjątkiem pochodzenia z robotników wykwalifikowanych - osoby te rzadko czytały książki, chociaż należy pamiętać, że zależności te nie są statystycznie istotne i mogą być przypadkowe. Interesująco kształtowało się czytelnictwo osób wychodzących z kategorii kierowników wyższego szczebla i specjalistów, którzy zostali pracownikami umysłowymi, właścicielami itd. (przedstawione w pierwszym wierszu tabeli 4). Wyróżniają się one największym czytelnictwem. Sugeruje to, że - zgodnie z hipotezą o maksymalizacji - może zależeć im na podkreślaniu dobrego rodowodu, chociaż może to być również efekt wyniesionej z domu „socjalizacji” do kultury czytania: jest ona „smakiem”, którego się nigdy nie traci.

\section{Wnioski}

Ruchliwość społeczna, a zwłaszcza ruchliwość międzypokoleniowa, jest jednym z ogniw funkcjonowania struktury społecznej. Można powiedzieć, że w społeczeństwach rynkowych wzory ruchliwości są rodzajem testu na przestrzeganie zasad sprawiedliwości przy obsadzaniu stanowisk, a także podstawą legitymizacji systemu politycznego, racjonalności ekonomicznej i akceptacji dla władzy. Jak jest w Polsce? Przedstawione tu analizy wskazują, że poziom ruchliwości w Polsce nie odbiega od innych społeczeństw rynkowych. Odsetek osób ruchliwych, czyli tych, które zmieniły przynależność klasową, kształtuje się na poziomie 60-70\% ogółu ludności. Podobnie jest w Wielkiej Brytanii, Stanach Zjednoczonych i innych państwach, w których analizy te prowadzono. Sformułuję ogólniejszy wniosek, że nie odbiega to od normy określającej zasady regulacji stosunków społecznych i uwarunkowań wynikających z konieczności dostosowywania kierunków ruchliwości do potrzeb wzrostu gospodarczego i nowych technologii. Ogniwem dopełniającym są wzory zawierania małżeństw. W społeczeństwie polskim dominuje heterogamia klasowa, co oznacza, że mężowie i żony rekrutują się na ogół z różnych pięter hierarchii społecznej. Przeważają więc względy związane z otwartością, a nie ze statusem społecznym. Heterogamia małżeńska utrzymuje się na stałym poziomie, chociaż wzory wyboru męża i żony kształtują się w postaci hierarchii pokrywającej się ze stratyfikacją klasową, tzn. małżeństwa najczęściej są zawierane między osobami zajmującymi podobne pozycje.

Od ruchliwości rozpatrywanej ze względu na jej konsekwencje dla struktury społecznej należy odróżnić skutki ruchliwości dla jednostek. Wyniki tej analizy prowadzą do wniosku, że nie należy przeceniać znaczenia przepływów międzypokoleniowych dla poziomu dochodów ani zachowań i postaw związanych z praktykami kulturowymi. Awans i degradacja klasowa, rozpatrywane niezależnie od innych cech położenia społecznego, nie oddziałują w znaczącym stopniu na dochody rodziny. Członkowie kategorii zaliczanych do nowej inteligencji pochodzący z kategorii o niższym statusie społecznym nie bywają też częściej w filharmonii w porównaniu z inteligentami dziedziczącymi pozycje rodziców ani też nie różnią się od nich pod względem czytelnictwa książek. Z analiz prowadzonych na danych z tego samego badania, których tu nie przedstawiam, wynika, że ruchliwość nie jest dodatkowym impulsem do kupowania płyt muzycznych, czerpania przyjemności ze słuchania utworów jazzowych, znajomości muzyki klasycznej i kilku innych zachowań utożsamianych z kulturą dominującą. 
Nie oznacza to, że zmiana pozycji społecznej nie oddziałuje na zachowania jednostek. W Rosji awansowi w hierarchii klasowej towarzyszy wzrost upodobań do literatury pięknej ${ }^{34}$, w Anglii jest to związane z częstszym chodzeniem do teatru i upodobaniem do muzyki poważnej ${ }^{35}$, w Stanach Zjednoczonych ruchliwość redukuje skłonności do neurotyzmu i niestabilności emocjonalnej ${ }^{36}$. W Polsce przechodzenie z klasy robotniczej do nowej inteligencji jest czynnikiem sprzyjającym omniworyzmowi jedzenia, niezależnie od innych cech położenia społecznego ${ }^{37}$. Ruchliwość jest więc jednym z aspektów złożonego procesu kształtowania się zachowań i postaw, chociaż należy sądzić, że wywiera ona istotniejszy wpływ na mechanizmy makrosystemowe, które rzutują na kształt nierówności społecznych, co na ogół nie zależy od poczynań jednostek.

\section{Bibliografia}

Breen R., Jonsson J.O., Inequality of Opportunity in Comparative Perspective: Recent Research on Educational Attainment and Social Mobility, „Annual Review of Sociology” 2005, vol. 31, https://doi.org/10.1146/annurev. soc.31.041304.122232.

Breen R., Luijkx R., Social Mobility in Europe between 1970 and 2000 [w:] Social Mobility in Europe, red. R. Breen, Oxford University Press, Oxford-New York 2004, https://doi.org/10.1093/0199258457.003.0003.

Bukodi E., Goldthorpe J.H., Waller L., Kuha J., The Mobility Problem in Britain: New Findings from the Analysis of Birth Cohort Data , ${ }_{11}$ The British Journal of Sociology" 2015, vol. 66(1), https://doi.org/10.1111/1468-4446.12096.

Cabinet Office Opening Doors Breaking Barriers, 2011, http://download.cabinetoffice.gov.uk/social-mobility/ opening-doors-breakingbarriers.pdf.

Chan T., Turner H., Where Do Cultural Omnivores Come from? The Implications of Educational Mobility for Cultural Consumption, Paper presented at the International Sociological Association RC28 Conference in Budapest, April 2014, 2015, https://doi.org/10.1093/esr/jcx060.

Clifford P., Heath A.F., The political consequences of social mobility, ,Journal of the Royal Statistical Society. Series A"1993, vol. 156, https://doi.org/10.2307/2982860.

Coulangeon P., The Omnivore and the "Class Defector". Musical Taste and Social Mobility in Contemporary France, „Notes \& Documents" 2013, no. 3.

Daenekindt S., Roose H., Cultural chameleons, „Acta Sociologica” 2013, vol. 56(4), http://dx.doi. org/10.1177/0001699313496589.

Domański H., Czy sq w Polsce klasy społeczne, Krytyka Polityczna, Warszawa 2015.

Domański H., Karpiński Z., Intergenerational mobility and omnivorism in eating, „Apetite” 2017, vol. 121, https:// doi.org/10.1016/j.appet.2017.10.030.

34 J. Zavisca, The Status of Cultural Omnivorism: A Case Study of Reading in Russia, "Social Forces” 2005, vol. 84, s. 1233-1255, https://doi.org/10.1353/sof.2006.0042.

35 T. Chan, H. Turner, op. cit.

36 J.N. Houle, Mobility effects redux: does intergenerational mobility shape individual psychology?, 2007, https:// pdfs.semanticscholar.org/0059/8e1252481861f9be6506c0251ae2bc98d8c1.pdf?_ga=2.100381086. $1897240865.1594112533-1288889591.1592816157$.

37 H. Domański, Z. Karpiński, Intergenerational mobility and omnivorism in eating, „Apetite” 2017, vol. 121, s. $83-$ 92, https://doi.org/10.1016/j.appet.2017.10.030. 
Domański H., Mach B.W., Przybysz D., Otwartość polskiej struktury społecznej: 1982-2016, „Studia Socjologiczne” 2019, nr 1(232), https://doi.org/10.24425/122489.

Domański H., Przybysz D., Homogamia małżeńska i hierarchie społeczne, Wydawnictwo IFiS PAN, Warszawa 2007. Erikson R., Goldthorpe J.H., The Constant Flux: A Study of Class Mobility in Industrial Societies, Clarendon Press, Oxford 1992, https://doi.org/10.1177/000169939403700110.

Goldthorpe J.H., Jackson M., Intergenerational class mobility in contemporary Britain: Political concerns and empirical findings, "The British Journal of Sociology" 2007, vol. 58(4), https://doi.org/10.1111/j.1468-4446.2007.00165.x.

Goldthorpe J.H., Mills C., Trends in Intergenerational Class Mobility in Modern Britain: Evidence from National Surveys, 1972-2005, „National Institute Economic Review”2008, vol. 205(1), https://doi.org/10.1177/0027950108096591.

Griswold W., McDonnell T., Wright N., Reading and the Reading Class in the Twenty-First Century, "Annual Review of Sociology" 2005, vol. 31, https://doi.org/10.1146/annurev.soc.31.041304.122312.

Houle J.N., Mobility effects redux: does intergenerational mobility shape individual psychology?, 2007, https:// pdfs.semanticscholar.org/0059/8e1252481861f9be6506c0251ae2bc98d8c1.pdf?_ga=2.100381086. $1897240865.1594112533-1288889591.1592816157$.

Hout M., Guest A.M., Intergenerational occupational mobility in Great Britain and the United States since 1850: comment, „American Economic Review” 2013, vol. 103(5), https://doi.org/10.1257/aer.103.5.2021.

Li Y., Devine F., Is social mobility really declining? Intergenerational class mobility in Britain in the 1990s and the 2000s, „Sociological Research Online” 2011, vol. 16(3), https://doi.org/10.5153/sro.2424.

Long J., Ferrie J., Intergenerational occupational mobility in Great Britain and the United States since 1850, „American Economic Review" 2013, vol. 103(4), https://doi.org/10.1257/aer.103.5.2041.

Mach B.W., Intergenerational mobility in Poland: 1972-88-94 [w:] Social Mobility in Europe, red. R. Breen, Oxford University Press, Oxford-New York 2004, https://doi.org/10.1093/0199258457.003.0011.

Newman K.S., Falling from grace: downward mobility in the age of affluence, University of California Press, Berkeley 1999, https://doi.org/10.2307/2073805.

Pareto V., Traktat o socjologii ogólnej, 1916.

Payne G., A New Social Mobility? The political redefinition of a sociological problem, "Contemporary Social Science" 2012, vol. 7(1), https://doi.org/10.1080/21582041.2011.652360.

Pfeffer F.T., Hertel F.R., How Has Educational Expansion Shaped Social Mobility Trends in the United States?, „Social Forces" 2015, vol. 94(1), https://doi.org/10.1093/sf/sov045.

Sawiński Z., Domański H., Wymiary struktury społecznej. Analiza porównawcza, Ossolineum, Wrocław 1986.

Schumpeter J.A., Imperialism and Social Classes, Basil Blackwell, Oxford 1951.

Słomczyński K.M., Białecki I., Domański H., Janicka K., Mach B.W., Sawiński Z., Sikorska J., Zaborowski W., Struktura społeczna: schemat teoretyczny i warsztat badawczy, Wydawnictwo IFiS PAN, Warszawa 1989.

Social Mobility in Europe, red. R. Breen, Oxford University Press, Oxford-New York 2004, https://doi.org/10.109 3/0199258457.001.0001.

Sorokin P., Ruchliwość społeczna, Wydawnictwo IFiS PAN, Warszawa 2009 (wydanie oryginalne - 1927).

Xie Y., Killewald A., Intergenerational occupational mobility in Great Britain and the United States since 1850: Comment, „American Economic Review” 2013, vol. 103(5), https://doi.org/10.1257/aer.103.5.2003.

Zagórski K., Rozwój, struktura i ruchliwość społeczna, PWN, Warszawa 1978.

Zavisca J., The Status of Cultural Omnivorism: A Case Study of Reading in Russia, "Social Forces” 2005, vol. 84, https:// doi.org/10.1353/sof.2006.0042. 